DOI: $10.4274 / m j i m a .2018 .12$

Mediterr J Infect Microb Antimicrob 2018;7:12

Erişim: http://dx.doi.org/10.4274/mjima.2018.12

\title{
Crimean-Congo Hemorrhagic Fever in Pregnancy: Two Cases from Turkey and a Review of the Literature
}

\author{
Gebelikte Kırım Kongo Kanamalı Ateşi: Türkiye'den Iki Olgu Sunumu ve Literatür Derlemesi
}

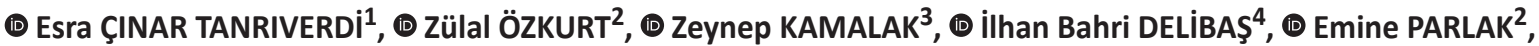 \\ ๑) Berrin GÖKTUĞ KADIOĞLU ${ }^{5}$ \\ ${ }^{1}$ Atatürk University Faculty of Medicine, Department of Medical Education, Obstetrics and Gynecology MD, Erzurum, Turkey \\ ${ }^{2}$ Atatürk University Faculty of Medicine, Department of Infectious Diseases and Clinical Microbiology, Erzurum, Turkey \\ ${ }^{3}$ Buhara Hospital, Clinic of Obstetrics and Gynecology, Erzurum, Turkey \\ ${ }^{4}$ Gaziosmanpaşa University Faculty of Medicine, Department of Obstetrics and Gynecology, Tokat, Turkey \\ 5 University of Health Sciences, Erzurum Region Health Practice and Research Center, Department of Obstetrics and Gynecology, Erzurum, Turkey
}

\section{Abstract}

Crimean-Congo hemorrhagic fever (CCHF) is a serious viral disease. There are limited data on the clinical course of the disease during pregnancy. Here, we report two pregnant women with CCHF and literature review. Tick bite history, thrombocytopenia, leukopenia, and elevated liver enzymes were noted in both cases. The diagnosis was confirmed via CCHF virus-polymerase chain reaction (PCR) or IgM positivity. Supportive therapy was given to the patients, but ribavirin was not administered. Blood product was not required in one of the patients, and three apheresis thrombocyte suspensions were given to the other one. Both patients were treated successfully and improved. Pregnancy was terminated in one and continued without any problem in the other patient and a healthy baby was born. Overall there were 42 CCHF diagnosed pregnants reported in the literature and 15 of these were from Turkey (including our cases). Maternal and fetal mortality rates were found to be 6.6\% (1/15) and 40\% (6/15), respectively in Turkish patients. Fetal loss was observed in 3/4 in the first trimester, 2/7 in the second trimester, and 1/4 in the third trimester. There was hemorrhage in 8 of 15 pregnants (53.3\%). Maternal mortality was recorded in 1/8 (12.5\%) patients with bleeding, and there was fetal loss in $6 / 6$ (100\%). CCHF during pregnancy is a rare but an important clinical problem. Clinical severity is of great importance for mother survival, and both gestational week and mother's clinical condition seem to be important for fetus health. The virus may be transmitted by the vertical mode and fetal infection may cause intrauterine death. CCHF should be considered in women with vaginal bleeding in endemic areas.

Keywords: Crimean-Congo hemorrhagic fever, tick, pregnancy, maternal mortality, fetal mortality

\section{Öz}

Kırım Kongo kanamalı ateşi (KKKA) ciddi bir viral hastalıktır. Hastalığın gebelikteki seyri ile ilgili bilgiler sınırlıdır. Burada KKKA'lı gebe iki olgunun sunumu ve literatür incelemesi yapıldı. Her iki olguda da trombositopeni, lökopeni, karaciğer ve kas enzimlerinde yükseklik, kene ısırması öyküsü vardı. Tanı KKKA virüsü-polimeraz zincir reaksiyonu (PZR) veya IgM olumluluğu ile konfirme edildi. Hastalara sadece destek tedavisi verildi, ribavirin kullanılmadı. İlk olguya kan ürünü transfüzyonu gerekmedi, ikinci olguya üç ünite aferez trombosit süspansiyonu verildi. İki hasta da başarıyla tedavi edildi ve iyileşti. İlk olguda gebelik düşükle sonuçlanırken, ikinci olguda problem saptanmadı ve bebek sağlıklı olarak dünyaya geldi. Literatürde bildirilen KKKA tanılı gebe olgu sayısı 42 olup, iki olgumuzla birlikte Türkiye'den bildirilen sayı 15 olgudur. Ülkemizden bildirilen olgularda anne ölüm oranı \%6,6 (1/15) ve fetal/neonatal kayıp oranı \%40'dır (6/15). İlk trimesterde \%75 (3/4), ikinci trimesterde \%28 (2/7), üçüncü trimesterde \%25 (1/4) fetal kayıp olduğu görülmektedir. Gebelerin \%53,3'ünde (8/15) kanama görülmüştür. Kanaması olan gebelerde ölüm oranı \%12,5 (1/8) iken, fetal kayıp oranı \%100 (6/6) bulunmuştur. Gebelikte KKKA nadir fakat oldukça önemli bir klinik problemdir. Kliniğin ağırlığı hem anne, hem bebek sağkalımında önemli bir belirleyici iken, fetüs kaybı için gebelik haftasının da önemli role sahip olduğu görülmektedir. Virüs vertikal olarak bulaşabilir ve fetüsün enfeksiyonu intrauterin ölüme neden olabilir. Endemik bölgelerde, anormal vajinal kanaması olan kadınlarda KKKA akılda bulundurulmalıdır.

Anahtar Kelimeler: Kırım Kongo kanamalı ateşi, kene, gebelik, anne ölümü, bebek ölümü

Cite this article as: Çınar Tanrıverdi E, Özkurt Z, Kamalak Z, Delibaş IB, Parlak E, Göktuğ Kadıoğlu B. Crimean-Congo Hemorrhagic Fever in Pregnancy: Two Cases from Turkey and a Review of the Literature. Mediterr J Infect Microb Antimicrob. 2018;7:12. 


\section{Introduction}

Crimean-Congo hemorrhagic fever (CCHF) is a tick-borne viral hemorrhagic fever presenting with high fever and bleeding, and it may be fatal. Virus is transmitted through bite of infected ticks or direct exposure to infected animals or human blood, body fluids and other infected tissues, or via nosocomial route ${ }^{[1-6]}$. CCHF has been reported in Eastern Europe, Asia, Africa and Middle East. Farmers living in endemic areas are high-risk group. The disease is seen in endemic regions in spring and summer months. CCHF may lead to serious bleeding due to thrombocytopenia and/or coagulopathy ${ }^{[1-6]}$.

We have limited knowledge about the clinical course of CCHF in pregnancy. Here, we report two pregnant patients and a review of the literature about the clinical course of CCHF in pregnancy.

\section{Case Reports}

\section{Case 1}

A 32-year-old pregnant was admitted to our emergency department with the complaints of headache, myalgia, weakness, fever, and vaginal bleeding. A nine-week singlelive fetus had been detected on ultrasound (US) a week ago, but we observed no fetal image on US examination. The endometrium was thickened and in irregular form, and active vaginal bleeding was present. The B-HCG level was $7500 \mathrm{U}$. On admission, her blood pressure was $100 / 60 \mathrm{mmHg}$, pulse was $92 / \mathrm{min}$, fever was $39^{\circ} \mathrm{C}$. She was hospitalized with the diagnosis of incomplete abortion and curettage was performed. Physical examination revealed oropharyngeal hyperemia, hepatomegaly, and butterfly rash. Blood analysis showed bicytopenia (platelet: $4800 \mathrm{~mm}^{3} / \mathrm{dL}$, leukocyte: $2200 \mathrm{~mm}^{3} / \mathrm{dL}$ ) increased liver enzymes [aspartate aminotransferase (AST): 94 $\mathrm{U} / \mathrm{L}$ and the following values: alanine aminotransferase (ALT): $225 \mathrm{U} / \mathrm{L}]$, lactate dehydrogenase (LDH): $1795 \mathrm{U} / \mathrm{L}$, alkaline phosphatase: $94 \mathrm{U} / \mathrm{L}$, gamma glutamil transferase (GGT): 288 $\mathrm{U} / \mathrm{L}$, and creatine phosphokinase (CPK): $815 \mathrm{U} / \mathrm{L}$. During follow up, liver and muscle enzymes were observed to be increased (AST: $225 \mathrm{U} / \mathrm{L}, \mathrm{ALT}: 373 \mathrm{U} / \mathrm{L}, \mathrm{LDH}: 1900 \mathrm{U} / \mathrm{L}$ and CPK: $815 \mathrm{U} / \mathrm{L}$ ). Coagulation tests were normal and hepatitis markers were negative. She had a history of tick bite on the gluteal region a week ago, thus, the patient was referred to the infection diseases clinic with the diagnosis of CCHF. The diagnosis was confirmed by polymerase chain reaction (PCR). Supportive therapy was given. Ribavirin treatment was not started. After ten days, vaginal bleeding stopped, patient's general condition and laboratory findings improved and she was discharged with full recovery.

\section{Case 2}

A pregnant with a history of tick bite was admitted with the complaints of fever, myalgia, nausea, and vomiting. On physical examination, facial hyperemia (butterfly rash), hepatosplenomegaly, and fever were noted (Figure 1). Obstetric US showed a 5-week fetal pole. There was no vaginal bleeding. Thrombocytopenia $\left(23.000 \mathrm{~mm}^{3} / \mathrm{dL}\right)$, leukopenia $\left(1200 \mathrm{~mm}^{3} / \mathrm{dL}\right)$, and elevated liver and muscle enzymes (ALT: $350 \mathrm{U} / \mathrm{L}$, AST: 480 U/L, LDH: $450 \mathrm{U} / \mathrm{L}, \mathrm{CK}: 350 \mathrm{U} / \mathrm{L}$ ) were recorded. The diagnosis was was confirmed by CCHFV-PCR positivity. Supportive therapy was given to the patient without ribavirin. Three units of apheresis thrombocyte were given. During hospitalization, obstetric US was repeated several times and was found to be normal. The mother was treated successfully. After one week, the patient completely recovered, and was discharged. Pregnancy continued without any problem. At follow-up three months after discharge, a live-fetus was observed by means of US. The baby was born without any complication. Since the patient's husband did not have any complaint, he was not tested for CCHF.

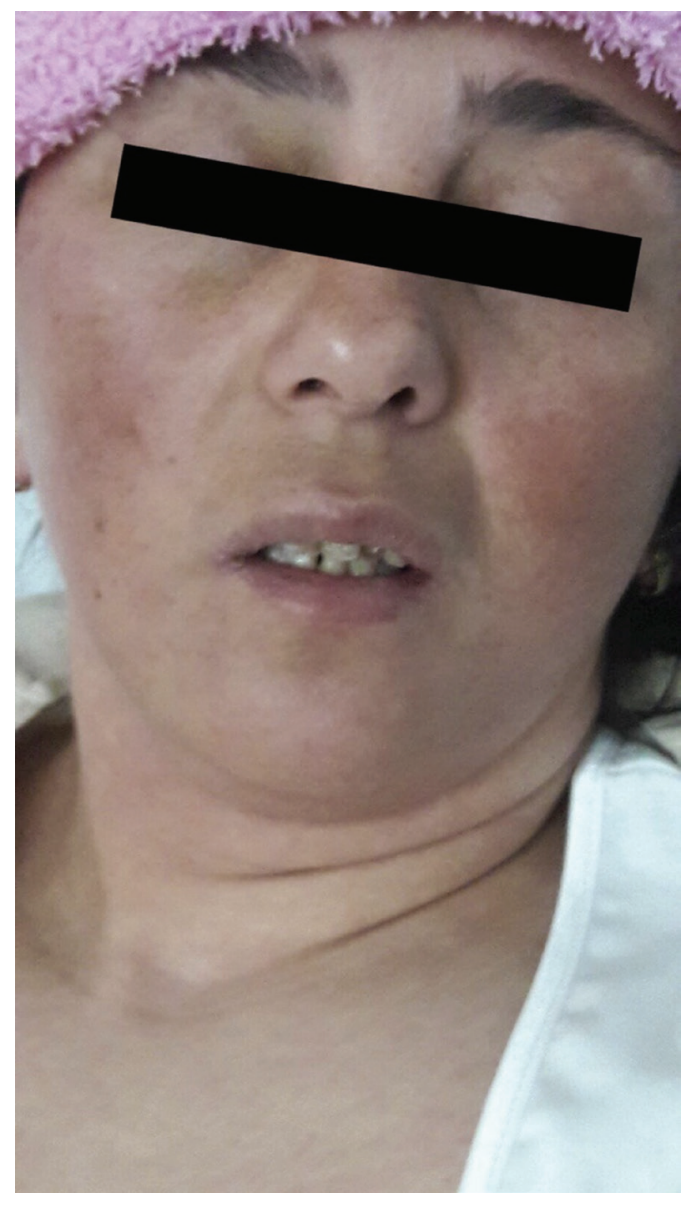

Figure 1. Butterfly rush on face of the patient with CrimeanCongo hemorrhagic fever 


\section{Review of the Literature}

Web of Science, PubMed, and Google Scholar database were scanned for pregnancies with CCHF. Articles published between February 1979 and January 2018 were included. Keywords were as follows: "Pregnancy", "Crimean-Congo hemorrhagic fever", "fetus", and "newborn". There were a total of 43 reported cases and 15 of these were from Turkey ${ }^{[7-13]}$. One case was excluded due to duplication. Cases reported from Turkey are shown in Table 1.

Ergonul at al. ${ }^{[7]}$ reported the first three cases of CCHF in pregnancy from Turkey. The first case was a pregnant at the $38^{\text {th }}$ week of gestation and was prediagnosed with HELLP syndrome. Delivery was via cesarean section. CCHF was diagnosed by PCR and ribavirin treatment was commenced. On the fifth postoperative day, the patient was re-operated because of intraabdominal hemorrhage. After intensive fresh frozen plasma and platelet infusion, the patient was discharged with full recovery, however, the baby died due to massive hemorrhage. The second case was a pregnant woman at the $19^{\text {th }}$ week of gestation who was infected with CCHF. Ribavirin was not used in this case. The fetus was lost at the $22^{\text {th }}$ gestational week. The third case was a pregnant woman at the $28^{\text {th }}$ week of gestation who was diagnosed with CCHF. She died with the fetus ${ }^{[7]}$. Dizbay et al. ${ }^{[8]}$ reported a case of CCHF infection in a 36-week pregnant woman who received ribavirin treatment resulting in survival of the mother and the baby. They did not find any clinical and laboratory findings related to CCHF. In our cases, only supportive therapy was administered and ribavirin was not used.
Gozel at al. ${ }^{[9]}$ reported five pregnant women with CCHF infection. In only one case, CCHF infection was acquired during the first trimester resulting in abortion. The others had no complication and reached a healthy full-term gestation and delivered healthy babies. Duygu et al. ${ }^{[10]}$ reported two pregnant women with $\mathrm{CCHF}$, one in the $17^{\text {th }}$ week and the other in the $20^{\text {th }}$ week of pregnancy. Both delivered healthy babies. Our first pregnant had to undergo an abortion in the $9^{\text {th }}$ week of pregnancy. The other patient delivered a full-term healthy baby without any complication.

In their systematic review and case series from Russia, Kazakhstan and Turkey, Pschenichnaya et al. ${ }^{[12]}$ analyzed a total of 42 pregnant with CCHF. Maternal and fetal mortality rates were reported to be $34 \%(14 / 41)$ and $58.5 \%$ (24/41), respectively. In addition, they found no significant difference in maternal and fetal/neonatal mortality between the first 20 weeks of pregnancy and 20-40 weeks. They reported that hemorrhage was associated with maternal and fetal/neonatal death. Dedkov et al. ${ }^{[13]}$ reported that CCHFV easily penetrated the placental barrier without significant selection of viral populations. They concluded that the risk of CCHFV-induced death of the fetus was extremely high in pregnant women with CCHF.

Up to now, overall 15 pregnant CCHF cases have been reported in the literature from Turkey including our cases ${ }^{[7-11]}$. Only one mother died due to intracerebral hemorrhage. Maternal and fetal/ neonatal mortality rates were found to be $6.6 \%(1 / 15)$ and $40 \%$ (6/15), respectively in Turkish cases (Table 1). Fetal mortality was

Table 1. Clinical course of Crimean-Congo hemorrhagic fever in pregnancy from Turkey

\begin{tabular}{|c|c|c|c|c|c|c|c|}
\hline Cases & $\begin{array}{c}\text { Pregnancy } \\
\text { week }\end{array}$ & $\begin{array}{l}\text { Mother } \\
\text { outcome }\end{array}$ & $\begin{array}{c}\text { Baby } \\
\text { outcome }\end{array}$ & $\begin{array}{c}\text { Baby } \\
\text { infection }\end{array}$ & Ribavirin & Hemorrhage & Birth time \\
\hline \multirow{3}{*}{ Ergonul et al.[7] } & 38 & Survival & Exitus & + & + & Present & Term \\
\hline & 19 & Survival & Exitus & + & - & Present & $22^{\text {th }}$ week \\
\hline & 28 & Exitus & Exitus & + & - & Present & Term \\
\hline Dizbay et al.[8] & 36 & Survival & Survival & - & + & Present & $36^{\text {th }}$ week \\
\hline Aydemir et al.[11] & 30 & Survival & Survival & $\mathrm{N}$ & - & No & $37^{\text {th }}$ week \\
\hline \multirow{2}{*}{ Duygu et al.[10] } & 17 & Survival & Survival & $\mathrm{N}$ & - & Present & Term \\
\hline & 20 & Survival & Survival & $\mathrm{N}$ & - & No & Term \\
\hline \multirow{5}{*}{ Gozel et al.[9] } & 8 & Survival & Abortion & - & - & Present & - \\
\hline & 18 & Survival & Survival & $\mathrm{N}$ & - & No & Term \\
\hline & 20 & Survival & Survival & $\mathrm{N}$ & - & No & Term \\
\hline & 21 & Survival & Survival & $\mathrm{N}$ & - & No & Term \\
\hline & 32 & Survival & Survival & $\mathrm{N}$ & - & No & Term \\
\hline Pshenichnaya et al.[12] & 4 & Survival & Abortion & $\mathrm{N}$ & - & Present & - \\
\hline \multirow{2}{*}{$\begin{array}{l}\text { Çınar Tanrıverdi et al. } \\
\text { (present case) }\end{array}$} & 9 & Survival & Abortion & $\mathrm{N}$ & - & Present & - \\
\hline & 5 & Survival & Survival & $\mathrm{N}$ & - & No & Term \\
\hline Exitus/survival & 15 & $1 / 15(6.6 \%)$ & $6 / 15(40 \%)$ & & $2 / 15(13.3 \%)$ & $8 / 15(53 \%)$ & \\
\hline
\end{tabular}

N: No data 
found in 3/4 in the first trimester, 4/8 in the first 20 weeks, and 2/7 in the second 20 weeks. Unlike what Pschenichnaya et al. ${ }^{[12]}$ reported, fetal mortality was found to be different in terms of pregnancy period in our study. Hemorrhage was found in 8 of 15 pregnant women (53.3\%). Mortality was recorded in 1/8 mothers without bleeding and in 6/6 fetuses of whose mothers were with bleeding. Therefore, hemorrhage that determines the severity of the disease affects both maternal and fetal mortality rates.

\section{Discussion}

The risk groups for CCHF are farmers, slaughterhouse, agriculture and forest workers, veterinarians, healthcare workers and laboratory technicians working in endemic areas. The most common transmission route of the disease is ticks ${ }^{[2]}$. Both patients in this study were farmers and were having a tick bite history.

There is limited experience about the clinical course of CCHF during pregnancy. Transmission of CCHF infection may be intrauterine and/or perinatal during pregnancy. It may lead to abortion as a neonatal complication and death of the baby. The cause for abortion may be vaginal bleeding and/or intrauterine infection. Perinatal results vary according to the severity of maternal infection and gestational weeks ${ }^{[7,13]}$.

There is no specific antiviral treatment for CCHF. Ribavirin, which is effective against RNA viruses, has been shown to prevent replication of viruses in in vitro experiments, but the use of ribavirin is controversial in $\mathrm{CCHF}^{[2-6]}$. Ribavirin is embryolethal and teratogenic. It is a Federal Drug Administration Pregnancy Category $X$ product and contraindicated in pregnant women ${ }^{[14]}$. Tatar et al. ${ }^{[15,16]}$ showed genotoxic effect of ribavirin in patients with CCHF. Roberts at al. reported six outcomes with birth defects (torticollis, hypospadias, polydactyly and a neonatal tooth, glucose-6-phosphate dehydrogenase deficiency, ventricular septal defect and cyst of 4 th ventricle of the brain) in 49 live births with ribavirin direct exposure and 69 live births following indirect ribavirin exposure. Ribavirin is contraindicated also in men whose partners may become pregnant. Additionally, females and female partners of males using ribavirin must avoid pregnancy during treatment and for six months after ribavirin treatment has stopped ${ }^{[17]}$.

Ribavirin was not given in our patients, and in all but two cases reported from Turkey. Aydemir et al. ${ }^{[11]}$ have reported an infant born at the $37^{\text {th }}$ week of gestation to a mother with CCHF. Ribavirin was not used in this case. PCR test was negative and the baby, who was born small for gestational age, did not develop any signs or symptoms of CCHF during one-week observation.

Maternal and fetal mortality rates are lower in Turkish cases than in others reported by Pshenichnaya et al. ${ }^{[12]}$. In that report, some cases occurred between 1979 and 2016 and CCHF was not widely recognised at this period. The Ministry of Health of Turkey established well organized healthcare centers and provided education for doctors for early diagnosis and treatment of patients with CCHF. Additionally, general health insurance system has provided Turkish people early healthcare services including air medical services. Algorithms for diagnosis and treatment of CCHF are determined and all healthcare professionals working in endemic areas have been informed accordingly. All these measures might have reduced the rates of CCHF associated mortality in Turkey.

Limitation of this study was its retrospective form. However, the study included valuable global data related with CCHF in pregnancy. Comparison of Turkish and other cases was important to provide information on national mortality rates and future strategies.

\section{Conclusion}

Severity of disease is an important parameter for mother survival. Both gestational week and mother's clinical presentation are important for fetal viability during CCHF in pregnancy. CCHF virus may be transmitted vertically and fetal infection may cause intrauterine death. CCHF should be kept in mind for pregnant women admitted to hospital with the complains of thrombocytopenia, leukopenia, elevated liver enzymes, fever and vaginal bleeding in spring and summer seasons where ticks are active in endemic areas. Protection from tick bite is important especially during pregnancy.

\section{Ethics}

Informed Consent: Informed consent was received from the presented cases.

Peer-review: Externally and internally peer-reviewed.

\section{Authorship Contributions}

Surgical and Medical Practices: Z.K., Z.Ö., Concept: E.Ç.T., Design: Z.Ö., Data Collection or Processing: E.P., B.G.K., Analysis or Interpretation: Z.Ö., Literature Search: I.B.D., B.G.K., Z.K., Writing: E.Ç.T., Z.Ö.

Conflict of Interest: No conflict of interest was declared by the authors.

Financial Disclosure: The authors declared that this study received no financial support.

\section{References}

1. Leblebicioglu H. Crimean-Congo haemorrhagic fever in Eurasia. Int J Antimicrob Agents. 2010;36(Suppl 1):43-6.

2. Ozkurt Z, Kiki I, Erol S, Erdem F, Yilmaz N, Parlak M, Gundogdu M, Tasyaran MA. Crimean-Congo hemorrhagic fever in Eastern Turkey: clinical features, risk factors and efficacy of ribavirin therapy. J Infect. 2006;52:207-15. 
3. Leblebicioglu H, Bodur H, Dokuzoguz B, Elaldi N, Guner R, Koksal I, Kurt $\mathrm{H}$, Senturk GC. Case management and supportive treatment for patients with Crimean-Congo hemorrhagic fever. Vector Borne Zoonotic Dis. 2012;12:805-11.

4. Elaldi $N$, Bodur $H$, Ascioglu $S$, Celikbas A, Ozkurt $Z$, Vahaboglu $H$, Leblebicioglu H, Yilmaz N, Engin A, Sencan M, Aydin K, Dokmetas I, Cevik MA, Dokuzoguz B, Tasyaran MA, Ozturk R, Bakir M, Uzun R. Efficacy of oral ribavirin treatment in Crimean-Congo haemorrhagic fever: a quasiexperimental study from Turkey. J Infect. 2009;58:238-44.

5. Duygu F, Kaya $T$, Baysan P. Re-evaluation of 400 Crimean-Congo hemorrhagic fever cases in an endemic area: is ribavirin treatment suitable? Vector Borne Zoonotic Dis. 2012;12:812-6.

6. Ozkurt Z, Ozden K, Kiki I, Usanmaz M. Prognostic significance of antithrombin activity in patients with Crimean-Congo Hemorrhagic Fever. Eurasian J Med. 2011;43:83-6.

7. Ergonul O, Celikbas A, Yildirim U, Zenciroglu A, Erdogan D, Ziraman I, Saracoglu F, Demirel N, Cakmak 0, Dokuzoguz B. Pregnancy and CrimeanCongo haemorrhagic fever. Clin Microbiol Infect. 2010;16:647-50.

8. Dizbay M, Aktas F, Gaygisiz U, Ozger HS, Ozdemir K. Crimean-Congo hemorrhagic fever treated with ribavirin in a pregnant woman. J Infect. 2009;59:281-3.

9. Gozel MG, Elaldi N, Engin A, Akkar OB, Bolat F, Celik C. Favorable outcomes for both mother and baby are possible in pregnant women with CrimeanCongo hemorrhagic fever disease: a case series and literature review. Gynecol Obstet Invest. 2014;77:266-71.
10. Duygu F, Cicek AC, Kaya T. Crimean-Congo hemorrhagic fever and pregnancy: Two cases. Journal of Microbiology and Infectious Diseases. 2015;5:29-31.

11. Aydemir 0, Erdeve 0, Oguz SS, Dilmen U. A healthy newborn born to a mother with Crimean-Congo hemorrhagic fever: is there protection from transplacental transmission? Int J Infect Dis. 2010;14:450.

12. Pshenichnaya NY, Leblebicioglu H, Bozkurt I, Sannikova IV, Abuova GN, Zhuravlev AS, Barut $S$, Shermetova MB, Fletcher TE. Crimean Congo hemorrhagic fever in pregnancy: A systematic review and case series from Russia, Kazakhstan and Turkey. Int J Infect Dis. 2017;58:58-64.

13. Dedkov VG, Shchelkanov MY, Bushkieva BT, Rudenko TA, Kurdyukova OV, Galkina IV, Sapotsky MV, Blinova EA, Dzhambinov SD, Shipulin GA. A neonatal death associated with Crimean Congo hemorrhagic fever (Republic of Kalmykia, Russia, June 2016). Antiviral Res. 2017;146:146-8.

14. http://www.accessdata.fda.gov/drugsatfda_docs/label/2002/21511_ Copegus_lbl.pdf

15. Tatar A, Ozkurt Z, Kiki I. Genotoxic effect of ribavirin in patients with Crimean-Congo hemorrhagic fever. Jpn J Infect Dis. 2005;58:313-5.

16. Tatar A, Ozkurt Z, Hacimuftuoglu A, Yesilyurt A, Vancelik S. Evaluation of Ribavirin Genotoxicity with Sister Chromatid Exchange and Micronuclei Assays in Humans. Turk J Med Sci. 2009:39:241-6.

17. Roberts SS, Miller RK, Jones JK, Lindsay KL, Greene MF, Maddrey WC, Williams IT, Liu J, Spiegel RJ. The Ribavirin Pregnancy Registry: Findings after 5 years of enrollment, 2003-2009. Birth Defects Res A Clin Mol Teratol. 2010;88:551-9. 